\title{
Trade Measures of OECD Countries and the Decline in Exports of African Countries: Is Murky Protectionism Responsible?
}

\section{Adugna Lemi*}

Department of Economics, University of Massachusetts, Boston, USA

\begin{abstract}
Since the onset of the recent global financial crisis and the resulting trade downturn, there have been efforts to understand the channels through which financial crisis has been affecting global trade and to explain the overall welfare impact of the crisis. Most previous studies focus on finding the key factors that link the financial crisis to the trade crisis. Specifically, the role of limited access to trade credit, murky protectionism, behind-the-border measures, and fluctuations in demand components are implicated as the leading contributors to the downturn. The purpose of this study is to investigate the significance of two of these factors, namely, murky protectionism and demand components, in the context of trade among OECD and African countries during the crisis years. Author has drawn commodity-level data on bilateral trade flow and trade measures from the OECD and GTA databases, respectively, to empirically investigate the impacts of OECD countries' demand components and murky protectionisms on imports from African countries. The results confirm that OECD countries' demand components played a relatively lesser role in the downturn of imports from African countries, whereas trade measures, especially tariffs, quotas, and the so-called 'trade defense measures' had significant negative effects on OECD imports from African countries. GTA's evaluation of the trade measures, in terms of the nature of their likely impacts on trade flows, is, however, not confirmed in this study.
\end{abstract}

Keywords: Protectionism; Trade crisis; Import demand; Financial crisis; Africa

\section{Introduction}

The burgeoning trade measures that the OECD countries have implemented, pressured by domestic interest groups, during the recent global economic crisis have raised serious concerns especially among developing countries. This is despite repeated pledges from the advanced countries not to engage in trade distorting measures. Less developed counties, especially those in Africa, have seen their export values, but less so for export volumes, decline during the recent years of crisis. It is, however, not clear whether the decline in export values is due to the new trade measures, a decline in demand resulted from the global economic crisis, any other factor.

As a result of the 2008/2009 global financial crisis, the global flow in goods and services has faced setbacks, to say the least. Some label it as a trade crisis while others call it just a trade collapse [1]. Whatever label one likes to assign to it, the current consensus is that the world is in a mode of recovery, or sort of. Since the onset of the recent global financial crisis and the resulting trade downturn, there have been efforts to understand the channels through which financial crisis has been affecting global trade and to explain the overall welfare impact of the crisis. Most of the studies focus on finding the key factors that link the financial crisis to the trade crisis; limited access to trade credit, murky protectionism, behind-the- border measures, border measures, and fluctuations in demand components are implicated as the leading contributors to the downturn. The limited literature mainly focuses on description of the extent of the trade crisis so as to establish stylized facts and suggest some possible explanation for the downturn, forecast the future course of the global trade and recommend the need for the tightening of multilateral agreements by completing the Doha round [2-4]. Given the brief history of the recent crisis, it is expected that rigorous empirical studies are very limited at best. Of those available studies, most either picked only one of their favorite contributing factors or attempt a global analysis and run into aggregation bias.

For some of the existing literature that went beyond just description of the events and presentation of professional guesses on the future direction, their conclusions are vague or too general. Others ventured only for a bigger picture perhaps scared by data limitations. In between the two extreme ends, there are few others that ventured deep in their analysis to look for a statistically and economically significant explanation for the downturn in trade flow during the crisis years [5]. Most empirical studies can fall within the latter framework, in that they attempt to look into one or two of these suspected factors that link the financial crisis to the trade crisis. Some focus only on lack of access to trade credit and others on the demand components [6,7]. Still others went further into details and looked at not only the downturn in import value, but also highlight on the significance of the changes in the intensive and extensive trade margins as well as prices, the impact on intermediate inputs trade and the need to distinguish between the production and trade of durable and non-durable goods in explaining the contraction in trade and GDP [8-10].

Anderson, Tewolde and Henn and McDonald are the closest in spirit to the present study. The former study looks at the role of demand components while the latter investigates the importance of trade measures during the crisis years $[7,11]$. The contribution of the present study is to combine both factors (demand components and trade measures) and empirically test for their importance in the context of imports of OECD countries from African countries and hence fill this gap by investigating this issue empirically for the sample countries.

Building on the above two studies, the present study aims to look

*Corresponding author: Adugna Lemi, Associate Professor, Department of Economics, University of Massachusetts, Boston, USA, Tel: +1 617287 5000; E-mail: adugna.lemi@umb.edu

Received November 02, 2015; Accepted January 19, 2016; Published January 22, 2016

Citation: Lemi A (2016) Trade Measures of OECD Countries and the Decline in Exports of African Countries: Is Murky Protectionism Responsible? J Glob Econ 4: 171. doi:10.4172/2375-4389.1000171

Copyright: (C) 2016 Lemi A. This is an open-access article distributed under the terms of the Creative Commons Attribution License, which permits unrestricted use, distribution, and reproduction in any medium, provided the original author and source are credited. 
into the impacts of two of the contending explanation for the downturn in OECD imports. As such the significance of this study is, therefore, threefold: First, it has important contribution to the ongoing discussion as to how much trade barriers hinder flow of trade, ceterius paribus $[7,11]$. Second, it sheds light on what to expect during crisis from trading partners severely affected by the crisis and to prepare oneself accordingly. Finally, for international organizations, such as the World Trade Organization, that serve as a platform to set global trade rules, the results from this study will provide insight to think about future negotiation agenda, in addition to the safeguard mechanism, as to what countries are allowed to do during such times of crisis.

\section{Data and Methodology}

To empirically address the above issues this study uses information on trade measures reported to the Global Trade Alert (GTA) together with a very detailed and rich OECD commodity-level trade data to study the impacts of the crisis-years trade measures and demand components of OECD countries on exports of African countries. Particularly, the study will further evaluate the impacts of implemented trade measures that were expected to certainly be harmful (labeled red) to those implemented trade measures that were expected to further liberalize trade flows (labeled green) as well as trade measures with ambiguous impacts on trade flows (labeled amber). Both the OECD and GTA datasets are very detailed to assess the impacts of these measures at (two- digit) commodity level. In addition to the total number of implemented measures, author has identified nine specific measures that are of great significance for African countries in particular, and less developed countries in general. Out of these nine ${ }^{1}$, export subsidies, import subsidies, non-tariff barriers, tariff measures, trade defense measures, and Quota are found to be the most important in terms of the number of affected tariff lines and sectors for exports of African countries.

Both the trade flow data from the OECD database and the trade measures data from Global Trade Alert (GTA) are detailed to the level of 2-digit commodity classification. In addition to the import and export variables, the OECD data library also reports three demand component (household consumption, government spending and gross fixed capital formation) for OECD countries. Imports and exports are in levels where as the other three demand components are as a share of Gross Domestic Product (GDP) of a country . Together with data on trade, demand components and trade measures, author has also use data on (gravity) control variables (i.e. distance, language, colonial history, etc.), as provided by the Institute for Research on the International Economy (CEPII), to estimate import demand equations for OECD countries for which complete data is available (list of sample countries and description of variables are reported in Table 1 in appendix.

The original GTA trade measures data includes variables on date of implementation, implementing countries, countries affected, type of trade measures, GTA evaluation on the potential impact of these measures, sectors affected, affected commodities, and whether the measures have been implemented, among others. One of the difficulties

${ }^{1}$ These are export subsidy, import subsidies, import ban, non-tariff barriers, tariff measures, trade defense measures, technical measures, quota, sanitary and phyto-sanitary measures, and local content requirements.

${ }^{2}$ Exports are entered the estimation in levels to avoid collinearity with the other demand components (since all sum

of the shares of all demand components adds up to 100). However, author has tried alternatives ways to incorporate imports and exports as share of GDP and still avoid collinearity. The results are more or less similar, with the signs unchanged but with slight variation in significance. Author has not reported the results that use shares of imports and exports to save space. in using this data was the way it was reported; that is for each trade measure entry several implementing countries, affected countries, affected sectors and affected commodities are reported. This makes it

\begin{tabular}{|c|c|c|c|c|}
\hline Measure Type & 2008 & 2009 & 2010 & Total \\
\hline Bail out/state aid measure & 32 & 142 & 59 & 233 \\
\hline Consumption subsidy & 1 & 3 & 1 & 5 \\
\hline Consumption subsidy, Export subsidy & & 1 & & 1 \\
\hline $\begin{array}{l}\text { Consumption subsidy, Public } \\
\text { procurement }\end{array}$ & & & 1 & 1 \\
\hline $\begin{array}{l}\text { Consumption subsidy, Sub-national } \\
\text { government }\end{array}$ & & 1 & & 1 \\
\hline Export subsidy & 5 & 20 & 12 & 37 \\
\hline Export subsidy, Export taxes or restrict & & & 5 & 5 \\
\hline $\begin{array}{l}\text { Export subsidy, Import subsidy, Trade } \\
\text { finance }\end{array}$ & & & 1 & 1 \\
\hline $\begin{array}{l}\text { Export subsidy, Public procurement, } \\
\text { Tariff }\end{array}$ & & 1 & & 1 \\
\hline Export taxes or restriction & 2 & 10 & 11 & 23 \\
\hline Import ban & & 1 & 4 & 5 \\
\hline Import ban, Local content requirement & & & 1 & 1 \\
\hline $\begin{array}{l}\text { Import ban, Sanitary and } \\
\text { Phytosantiary Measures }\end{array}$ & & 1 & 1 & 2 \\
\hline Import subsidy & & & 17 & 17 \\
\hline Intellectual property protection, Local & & 1 & & 1 \\
\hline $\begin{array}{l}\text { Intellectual property protection, } \\
\text { Migration }\end{array}$ & & & 1 & 1 \\
\hline Investment measure & & 14 & 20 & 34 \\
\hline $\begin{array}{l}\text { Investment measure, Local content } \\
\text { requirement }\end{array}$ & & & 1 & 1 \\
\hline $\begin{array}{l}\text { Investment measure, Migration } \\
\text { measure }\end{array}$ & & & 1 & 1 \\
\hline Investment measure, Non-tariff barrier & & & 1 & 1 \\
\hline $\begin{array}{l}\text { Investment measure, Other service } \\
\text { sector }\end{array}$ & & 1 & & 1 \\
\hline $\begin{array}{l}\text { Investment measure, Public } \\
\text { procurement }\end{array}$ & & 1 & & 1 \\
\hline Local content requirement & & 3 & 3 & 6 \\
\hline $\begin{array}{l}\text { Local content requirement, Public } \\
\text { procurement }\end{array}$ & & 3 & & 3 \\
\hline Migration measure & 1 & 19 & 14 & 34 \\
\hline $\begin{array}{l}\text { Non-tariff barrier (not otherwise } \\
\text { specified }\end{array}$ & 1 & 13 & 16 & 30 \\
\hline $\begin{array}{l}\text { Non-tariff barrier (not otherwise } \\
\text { specified }\end{array}$ & & & 1 & 1 \\
\hline $\begin{array}{l}\text { Non-tariff barrier (not otherwise } \\
\text { specified }\end{array}$ & & & 1 & 1 \\
\hline $\begin{array}{l}\text { Non-tariff barrier (not otherwise } \\
\text { specified }\end{array}$ & & & 1 & 1 \\
\hline Other service sector measure & & 3 & 2 & 5 \\
\hline Public procurement & 5 & 10 & 2 & 17 \\
\hline Public procurement, Tariff measure & & 1 & & 1 \\
\hline Quota (including tariff rate quotas) & 1 & 3 & 23 & 27 \\
\hline Sanitary and Phytosantiary Measures & & 4 & & 4 \\
\hline Tariff measure & 4 & 79 & 79 & 162 \\
\hline Technical Barrier to Trade & & 1 & 2 & 3 \\
\hline $\begin{array}{l}\text { Trade defense measure (AD, CVD, } \\
\text { safeguard }\end{array}$ & 3 & 333 & 119 & 455 \\
\hline Trade finance & 1 & 5 & 9 & 15 \\
\hline Total & 56 & 674 & 409 & 1,139 \\
\hline
\end{tabular}

Table 1: Types of trade measures implemented by OECD+ countries between 2008 and 2010. 
difficult to claim that this data is by country and by commodity as one would normally expect; especially to merge the data with the trade flow data that OECD has reported. Author has followed the following steps (strategies) to bring the data to confirm with the format of the trade flow data. First, for cases where several implementing countries are reported, author has created separate duplicate entries in the data for each country with all other information remaining the same for each entry. Second, for the cases where several commodities are reported in one entry, where possible, author has created separate duplicate entries; in cases where the list of commodities are too many, author has assigned code 99 (commodities not specified) for that entry. Note that in this study, author has used only those measures implemented between 2008 and 2010, excluding measures not implemented between these years. At the end of cleaning the data, author had left with 1140 trade measures between 2008 and 2010 (57 in 2008, 674 in 2009 and 409 in 2010). During these years there were about twenty different trade measure types as GTA has reported. Out of the twenty, trade defense measures (455 cases) top the list, followed by bail out/state aid measures (233 cases) and tariff measures (162 cases). Among these measures 73 were amber (measures with uncertain effects), 804 were red (trade limiting measures), and 264 were green (trade liberalizing measures (Table 1 in appendix). Commodity wise, Figure 1 reports sum of amber trade measures by commodity, the other two types of trade measures (red and green) have too many commodities to present here in graphs. Out of the three measures, OECD countries have imposed Amber measures on fewer commodities compared to red and green measures; red (or trade limiting) measures are by far used the most and were imposed on more commodities compared to green and amber measures. The two key variables that this study uses in estimation are the GTA evaluation codes and the types of the trade measures as GTA has reported. author has used the GTA evaluation variable to create three separate variables for the evaluation codes; trade limiting measures (Red), trade liberalizing measures (Green) and measures with uncertain effects (Amber) $)^{3}$. In addition to these evaluation

${ }^{3}$ Since red and green trade measures are highly correlated, separate import variables, author has also created separate trade measure variables for those measures which deemed to be significant for African countries and those measures with larger impact in terms of commodities/ sectors affected. As such author has created six dummy variables for the following trade measures: Export subsidy, import subsidy, quota, nontariff barriers, trade defense measures and tariff measures. author has estimated two separate import demand specifications, one that includes GTA coded trade measure evaluations and the other includes the six individual trade measure types. Both specifications include the demand components and the (gravity) control variables. In the remaining part of this section, author will present some descriptive statistics and finally present brief overview of the estimation methodology adopted in this study.

\section{African countries exports to the OECD countries during the crisis years}

The OECD commodity level trade flow data shows that African countries faced a significant decline in exports in 2009. Whereas there was a sign of recovery in 2010, mostly the recovery was noticeable for oil exporting countries as the graphs below indicate. In 2008, South Africa, Zambia and Tunisia were the top exporters of goods to the OECD countries ${ }^{4}$. Figures 2-4 reports commodity-weighted average trade flow between African and OECD countries for the years 2008, 2009 and 2010, respectively.

The commodity weighted average commodity-level exports of these countries were in the range of a bit over $\$ 50$ million to $\$ 75$ million in 2008. Note that for those countries with no blue bars, it just means that their average commodity exports are very negligible, but may not necessarily be zero.

In 2009, South Africa and Tunisia still dominated the list; however,

demand equations are estimated for red and green measures.

${ }^{4}$ Note that the blue colored bars are exports for African countries (or imports for OECD countries from African countries) and the brown colored bars are imports of African countries from OECD countries.

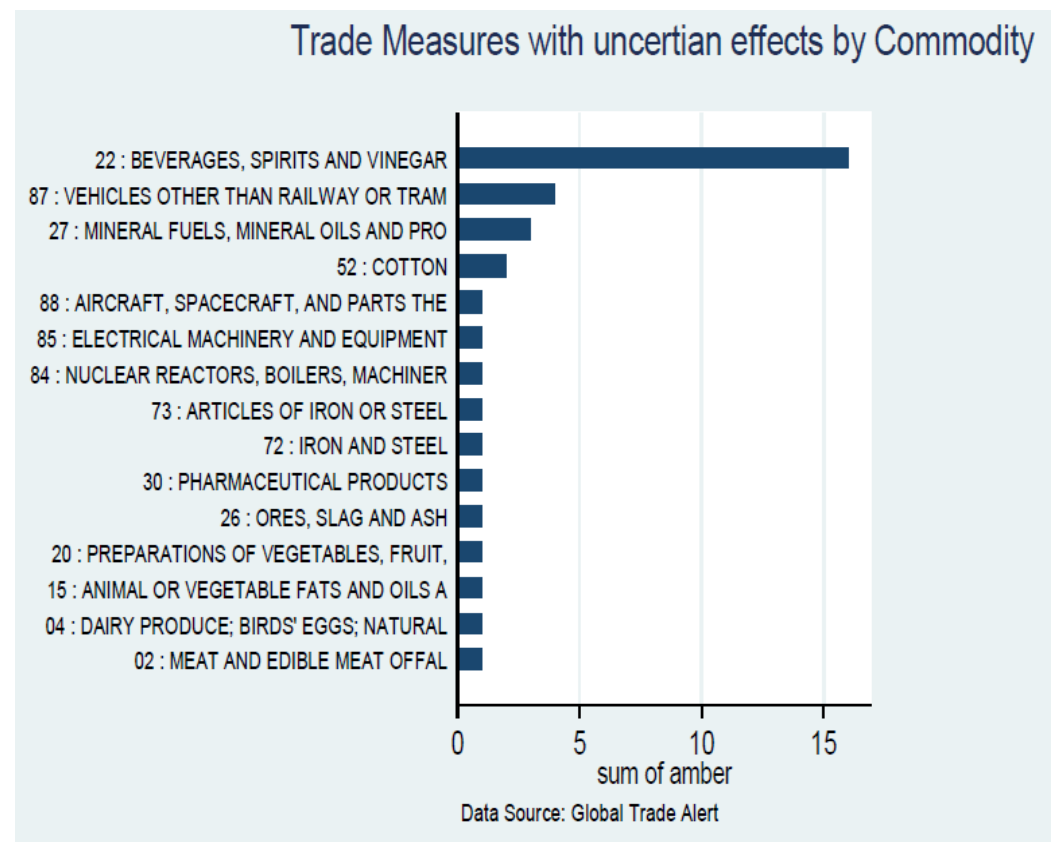

Figure 1: Trade Measures with uncertain effect implemented by OECD+ countries, 2008-2010. 


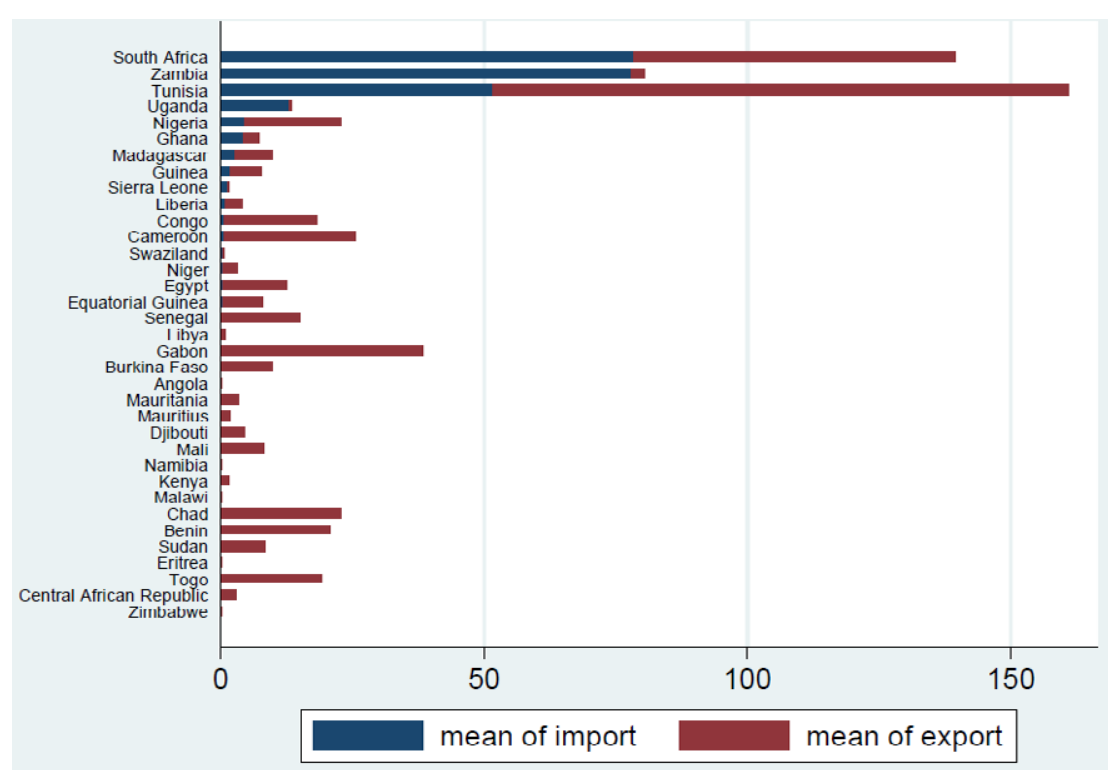

Figure 2: Commodity-weighted African countries' imports from and exports to OECD countries in 2008.

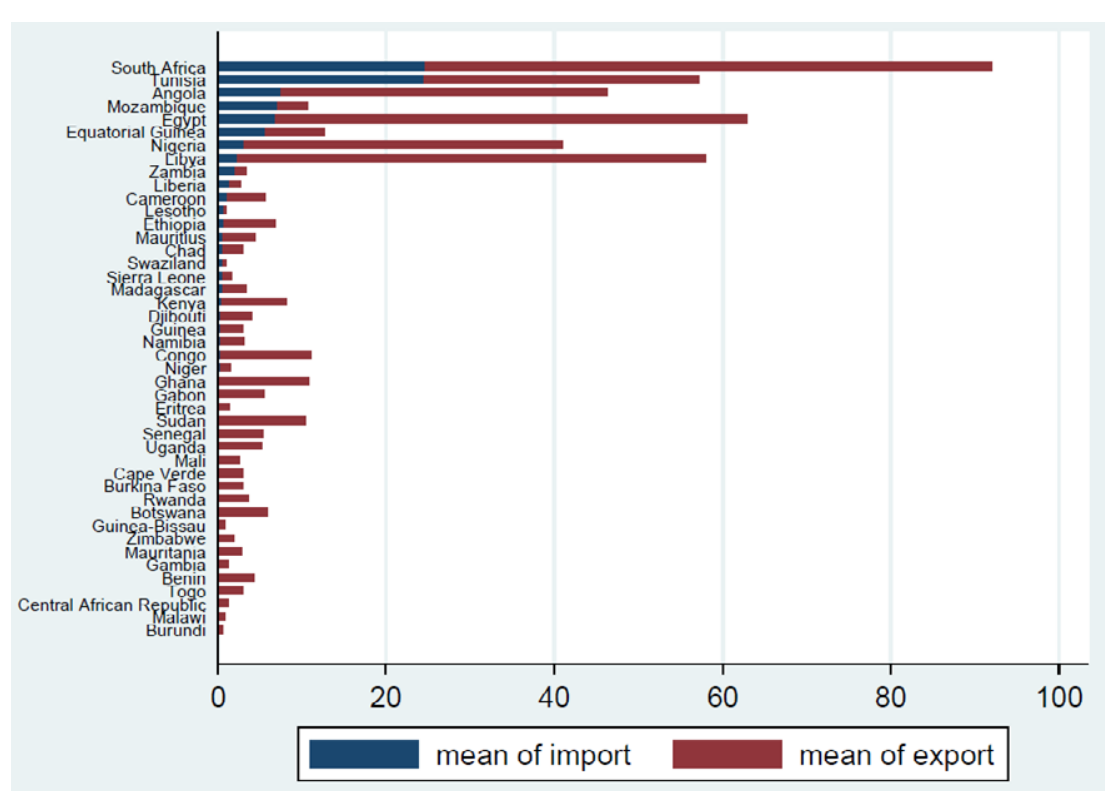

Figure 3: Commodity-weighted African countries' imports from and exports to OECD countries in 2009.

their average exports almost slashed to half of what it was in 2008 (Figure 3). It is important to also note that despite declined exports to OECD countries, African countries imports from OECD countries in fact had increased or at least remained constant. This could either be as a result of the export pushing (export subsidies) efforts that the OECD countries had instituted during the crisis years and/or as a result of the structure of the imports (i.e. necessities) of African countries. In 2010, there was a shake-up in the list of top countries in terms of average exports to OECD countries. In addition to South Africa and Tunisia, the four additional countries on the top lists are oil exporters: Libya, Nigeria, Angola and Sudan. In fact one can claim that the expected recovery was really not across the board for all goods and all countries.
Therefore, it is not far-fetched to claim that the crisis is not over for non-oil exporting countries of Africa. Could this pattern be explained by the impact of the new trade measures?

\section{The new trade measures affected many commodities}

The aggregate color coded (i.e. red, green and amber) trade measures, as per GTA evaluation, may have the expected impacts as indicated. However, during the years of crisis trade flow may also be affected by demand conditions in an importing country, and supply conditions in an exporting country. Having discussed the trade flow data in the previous paragraphs, it is not time to turn to the trade measures data from GTA. 


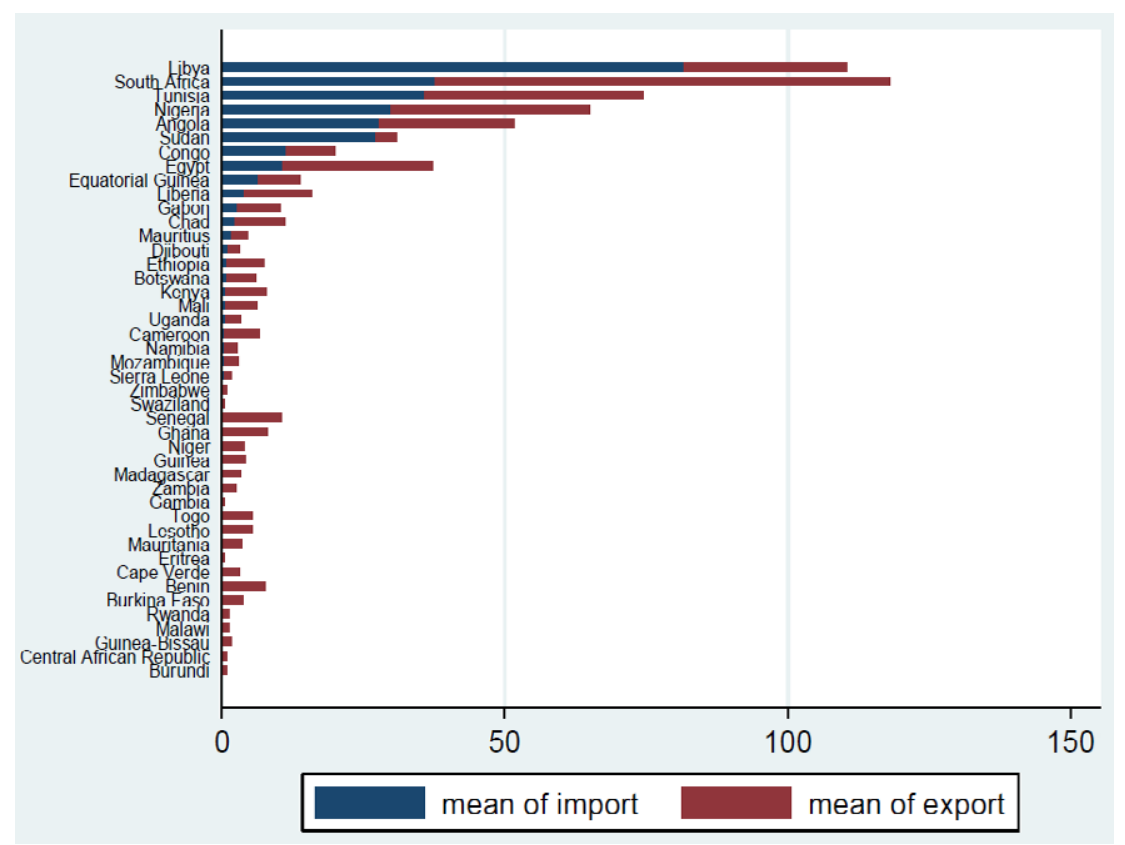

Figure 4: Commodity-weighted African countries' imports from and exports to OECD countries in 2010.

Note that in this study, author has used only those measures implemented between 2008 and 2010, excluding measures not implemented during these years. Out of the twenty, trade defense measures (455 cases) top the list, followed by bail out/state aid measures (233 cases) and tariff measures (162 cases) (Table 1). Among these measures 73 were amber, 804 were red, and 264 were green (Table 1 in appendix which lists aggregated trade measures by implementing OECD countries [sample countries] during the crisis years). Commodity wise, Figure 1 reports the sum of amber trade measures by commodity, the other two types of trade measures (red and green) have too many commodities to present here in graphs. Out of the three measures, OECD countries have imposed Amber measures on fewer commodities compared to red and green measures; red (or trade limiting) measures were by far used the most and also imposed on more commodities compared to green and amber measures.

Out of the top three commodity categories (beverages, spirits, and vinegar, vehicles other than railway or train, mineral fuels, mineral oils and products of their distillation) that faced amber measures during the crisis years, two of the categories are of significant importance for African countries exports. Perhaps, it may be the reason why only amber trade measures turn out to be significant in influencing African exports to OECD countries. Merging the trade flow and the trade measures data, author has estimated the import demand equations for OECD countries with different specifications to show the robustness of the results. From the trade measures, the two key variables are GTA's evaluation color codes and the types of the trade measures as reported to GTA. author has used the GTA evaluation variable to create three separate variables for the evaluation codes; trade limiting measures (Red), trade liberalizing measures (Green) and measures with uncertain effects (Amber) ${ }^{5}$. In addition to these evaluation variables, author has

5 Since red and green trade measures are highly correlated, separate import demand equations are estimated for red and green measures. For the robustness test, author has estimated the equations after dropping bailouts and state aids from the list of measures assuming that these measures may not be relevant for the case of Africa and they may not qualify as protectionism measures in the textbook also created separate trade measure variables for those measures which deemed to be significant for African countries and those measures with larger impacts in terms of commodities/sectors affected. As such author has created six dummy variables for the following trade measures: Export subsidy, import subsidy, quota, non-tariff barriers, trade defense measures and tariff measures. Author has estimated two separate import demand specifications, one that includes aggregated (GTA's color coded) trade measures and the other includes the six individual trade measure types. Both specifications include the demand components and the (gravity) control variables ${ }^{6}$.

\section{Estimation Methodology}

The selection of the estimation technique depends not only on the traditional specification tests to see which method best fits the data, but also the nature of the data, especially when it comes to panel data. The data author has used, as reported above, has more than the traditional two (say, country ID and year) panel variable. In this particular case, since the data is reported by reporting (OECD) countries and by commodity over time, it gives the data one extra dimension than the traditional panel dataset ${ }^{7}$. Since there is no panel data estimation technique that accounts for three component variables in single estimation equation; there are two ways to approach estimation of the import equations using the dataset at hand. One way is to just ignore the third component (say the commodity dimension) and estimate the equation using the traditional panel data estimation technique. The other approach is to account for the third dimension by manually introducing dummy variables for the component and include these dummy variables in the specification. The later approach works only if the estimation technique is of random effects type, otherwise all

definition of protection measures. However, the results remained the same.

${ }^{6}$ The gravity control variables include factors that link the trading partners in Africa and OECD (i.e. distance between trading partners, dummies for common language and colonial tie) and are obtained from Mayer, Thierry and Zignago, Soledad [12].

${ }^{7}$ In fact there may be the fourth dimension if we count trading partners of OECD countries, i.e., African countries. 
the dummy variables would be demeaned out of the specification under the fixed effects technique. Author has used both approaches to estimate the import demand equations to see the robustness of the results. author has reported the results from the standard panel data estimation techniques in Table 2.

The estimated import demand equation takes the following form:

$$
I M_{i j c}^{t}=\alpha_{i}+\beta_{i t} D C_{i t}+T M_{i t c}+\varepsilon_{i j c}
$$

Where IM is import of an OECD country (i) from a partner country in Africa $(j)$ at commodity level (c) over time (t); DC represents demand components and includes the shares of household consumption, investment spending, government spending and exports and TM refers to trade measures ${ }^{8}$. Except for the demand components, the other variables are at two-digit commodity levels. Theoretically it is expected that trade measures have negative effects on import demands whereas demand components have positive effects. As such imports from countries that impose trade measures affect African countries exports negatively. Similarly, a decrease in demand in an OECD country results in lower demand for imports from Africa. As we will see later in the results section, by and large the results are consistent with the theoretical expectations.

8 Ideally supply side capacity indicators of the exporting countries should be included in the estimation of import demand (export supply of SSA) of OECD countries. For this crisis-era (short-term issues) analysis, however, the focus is on the short-term factors, not as such long-term issues. Hence, it is safe to assume that supply side capacity variables may not be that significant in this setting.
Three different specifications of this import demand equation are estimated based on the type of the trade measure variable used in the estimation. First, the trade measures are entered as aggregate using the evaluation color codes that GTA provides. Second, instead of the aggregate trade measures, author has used dummies for individual trade measures to investigate the individual impacts of those trade measures with high expected impact on imports from Africa. Finally, due to high correlation between the red and green coded trade measures, it was not possible to include both aggregated trade measures in a single equation; therefore separate equation is estimated for the green and red coded trade measures.

In addition to the standard panel data estimation technique, author has employed two other estimation techniques; a technique that allows for different panel error component structure (say, heteroschedastic) and that a technique assumes some of the variables as endogenous. The generalized least squares panel estimation techniques allow for various error component structures to check for the robustness of the results. In this paper, author has allowed only for heteroscedatic error structures since other correlation structures require data with a longer period than possible in this dataset. In the case of suspected endogenous variables, for instance demand components, instrumental estimation technique is more appropriate. The Hausman-Taylor (HT) instrumental panel estimation technique is one approach that reports consistent estimators in the presence of endogenous variables. For the HT instrumental estimation, mostly demand components are

\begin{tabular}{|c|c|c|c|c|c|c|}
\hline & Standard & Standard & Heteroscedastic & Heteroscedastic & Hausman-Taylor & Hausman- Taylor \\
\hline & $\mathrm{b} / \mathrm{se}$ & $\mathrm{b} / \mathrm{se}$ & $\mathrm{b} / \mathrm{se}$ & $\mathrm{b} / \mathrm{se}$ & $\mathrm{b} / \mathrm{se}$ & $\mathrm{b} / \mathrm{se}$ \\
\hline \multirow[t]{2}{*}{$\begin{array}{l}\text { Household } \\
\text { Consumption }\end{array}$} & $0.73^{*}$ & $0.73^{*}$ & 0.01 & 0.01 & 1.26 & 1.26 \\
\hline & $(0.39)$ & $(0.39)$ & $(0.07)$ & $(0.07)$ & $(7.52)$ & $(7.52)$ \\
\hline \multirow[t]{2}{*}{ Business Investment } & $1.29^{* *}$ & $1.29^{\star \star}$ & -0.01 & -0.01 & -7.07 & -7.07 \\
\hline & $(0.56)$ & $(0.56)$ & $(0.14)$ & $(0.14)$ & $(5.34)$ & $(5.34)$ \\
\hline \multirow[t]{2}{*}{ Government Spending } & $1.58^{* *}$ & $1.58^{* *}$ & 0.06 & 0.06 & $29.86^{\star * *}$ & $29.86^{\star * *}$ \\
\hline & $(0.77)$ & $(0.77)$ & $(0.11)$ & $(0.11)$ & $(10.35)$ & $(10.35)$ \\
\hline \multirow[t]{2}{*}{ Exports } & $0.46^{\star \star *}$ & $0.46^{\star \star \star}$ & $0.23^{\star \star \star}$ & $0.23^{* * *}$ & $0.45^{\star \star \star}$ & $0.45^{\star \star \star}$ \\
\hline & $(0.12)$ & $(0.12)$ & $(0.01)$ & $(0.01)$ & $(0.03)$ & $(0.03)$ \\
\hline \multirow[t]{2}{*}{ Common Language } & 5.21 & 5.21 & -0.46 & -0.46 & -9.58 & -9.58 \\
\hline & $(6.56)$ & $(6.56)$ & $(1.10)$ & $(1.10)$ & (9.07) & $(9.07)$ \\
\hline \multirow[t]{2}{*}{ Distance from Capital } & -0.00 & -0.00 & $0.00^{*}$ & $0.00^{*}$ & -0.00 & -0.00 \\
\hline & $(0.00)$ & $(0.00)$ & $(0.00)$ & $(0.00)$ & $(0.00)$ & $(0.00)$ \\
\hline \multirow[t]{2}{*}{ Colonial Tie } & -12.82 & -12.82 & -0.80 & -0.80 & -15.54 & -15.54 \\
\hline & (10.38) & (10.38) & (1.98) & (1.98) & $(11.10)$ & $(11.10)$ \\
\hline \multirow[t]{2}{*}{ Amber Measures } & $65.43^{\star *}$ & $62.77^{*}$ & $5.89^{* * *}$ & $5.51^{* * *}$ & $64.30^{* \star *}$ & $63.30^{* * *}$ \\
\hline & $(32.52)$ & $(32.52)$ & $(1.94)$ & (1.91) & $(12.36)$ & $(11.44)$ \\
\hline \multirow[t]{2}{*}{ Restrictive Measures } & 2.66 & & 0.38 & & 1.00 & \\
\hline & $(2.71)$ & & $(0.70)$ & & $(6.13)$ & \\
\hline \multirow[t]{2}{*}{ Liberalizing Measures } & & -2.66 & & -0.38 & & -1.00 \\
\hline & & $(2.71)$ & & $(0.70)$ & & $(6.13)$ \\
\hline $\mathrm{N}$ & 3415.00 & 3415.00 & 3415.00 & 3415.00 & 3415.00 & 3415.00 \\
\hline chi2 & 23.30 & 23.30 & 635.03 & 635.03 & 317.62 & 317.62 \\
\hline r2_overall & 0.07 & 0.07 & & & & \\
\hline r2_between & 0.37 & 0.37 & & & & \\
\hline r2_within & 0.07 & 0.07 & & & & \\
\hline
\end{tabular}

*** Significant at $1 \%$, or $\mathrm{P}<0.01$

** Significant at $5 \%$, or $\mathrm{P}<0.05$

*Significant at $10 \%$, or $\mathrm{P}<0.10$

Numbers in parenthesis are standard errors.

Table 2: Estimations of Import demand equations with color-coded aggregate trade measures and demand components as explanatory variables. 
considered as endogenous with various alternative combinations of the components. The results from the alternative endogenous variable combinations are similar whether two or three of the components are used as endogenous. In estimations, where possible, author has also tried robustness test by using commodity codes, instead of country codes, as panel variable to estimate the import demand equations. Finally, author has grouped African countries into four regions (East, South, West and Central) to see if the results hold for the sub-sample. The results with the sub-sample are weak in terms of significance due to smaller sample size but the signs of the coefficients remained the same with that of the total sample estimation results. Results for the aggregated color code trade measures are reported in Table 2; Table 3 reports similar estimation results for the import demand equation as a function of individual trade measures, instead of color coded aggregate trade measures. As a robustness analysis, estimations in Table 4 reports results where commodity effects are controlled as panel variable and country effects are controlled by dummy variables.

\section{Results and Discussion}

The overall message from the various specifications is that both demand components and trade measures played a role in affecting imports of OECD countries from African countries during the crisis years. The results also show that the demand components played a relatively less role compared to trade measures in affecting imports from Africa. The new trade measures, specially, tariffs and trade defense measures were significant in explaining the downturn of African countries exports to OECD markets.

\section{Crisis years trade measures played a much bigger than the de- cline in OECD demand}

Demand component variables have the expected positive signs on import, with the exception of investment, which shows significantly negative association with OECD imports in at least one specification. The positive signs of the demand components are expected and in line with previous studies. It implies that a decline in OECD countries' demand is associated with a decline in imports from African countries. The exception with investment may have to do with the incentives provided by governments of OECD countries to source locally to benefit from any bailout or domestic investment incentive programs that governments provided during the crisis years. Unlike investment spending, share of government spending and exports had consistent and significant positive effects (more so for exports) impacts on import demand from Africa.

This implies that during the crisis years increases in the share of government spending and exports resulted in an increase in imports from Africa. As indicated in Anderson and Tewolde, OECD exports are one of the demand components with high import intensity and therefore, one expects that as exports increase (using more imported goods and services) import would increase as well [7]. As we will see below, it is not far-fetched to state that the negative effects of investment spending could be because the direct impacts of the murky protections, which were felt mainly by private investments, and as a result of the incentive diverted their spending to local or encouraged sources. One may wonder that since most of African countries' exports are not as such investment goods, how could an increase in investment in OECD countries resulted in a decline

9 Results from the standard panel data estimation techniques and from the robustness test estimations are more or less similar. Although the results from each specification are not contradictory, there are slight variations in the size and significance of some of the key variables. Note that author has tried estimation both with levels and with proportions of imports and exports variables, the results remained the same.

\begin{tabular}{|c|c|c|c|}
\hline & Standard & Heteroscedastic & Hausman-Taylor \\
\hline & $\mathrm{b} / \mathrm{se}$ & $\mathrm{b} / \mathrm{se}$ & $\mathrm{b} / \mathrm{se}$ \\
\hline \multirow[t]{2}{*}{ Household Consumption } & 0.20 & 0.20 & -0.47 \\
\hline & $(0.19)$ & $(0.49)$ & $(7.54)$ \\
\hline \multirow[t]{2}{*}{ Business Investment } & $1.19^{* *}$ & 1.19 & $-13.93^{* * *}$ \\
\hline & $(0.46)$ & $(1.00)$ & $(5.27)$ \\
\hline \multirow[t]{2}{*}{ Government Spending } & $1.12^{* *}$ & 1.12 & $33.18^{\star \star \star}$ \\
\hline & $(0.57)$ & $(0.89)$ & $(10.64)$ \\
\hline \multirow[t]{2}{*}{ Exports } & $0.45^{* * *}$ & $0.45^{* \star *}$ & $0.45^{\star \star *}$ \\
\hline & $(0.12)$ & $(0.03)$ & $(0.03)$ \\
\hline \multirow[t]{2}{*}{ Common Language } & -2.04 & -2.04 & -8.41 \\
\hline & $(6.50)$ & $(7.08)$ & $(9.08)$ \\
\hline \multirow[t]{2}{*}{ Colonial Tie } & -9.36 & -9.36 & -15.64 \\
\hline & $(9.51)$ & (9.39) & $(11.12)$ \\
\hline \multirow[t]{2}{*}{ Distance from Capital } & -0.00 & 0.00 & $-0.00^{*}$ \\
\hline & $(0.00)$ & $(0.00)$ & $(0.00)$ \\
\hline \multirow[t]{2}{*}{ Export Subsidy } & $-62.23^{* *}$ & $-62.23^{*}$ & -52.31 \\
\hline & $(25.85)$ & (34.36) & (34.79) \\
\hline \multirow[t]{2}{*}{ Import Subsidy } & $-53.63^{\star \star}$ & $-53.63^{\star \star}$ & $-47.37^{* *}$ \\
\hline & $(24.54)$ & $(22.11)$ & $(22.75)$ \\
\hline \multirow[t]{2}{*}{ Quota } & $-55.13^{* *}$ & $-55.13^{* * *}$ & $-48.08^{\star \star \star}$ \\
\hline & (24.48) & (14.85) & (15.61) \\
\hline \multirow[t]{2}{*}{ Non-Tariff M } & $-44.89^{*}$ & -44.89 & $-61.92^{*}$ \\
\hline & $(24.73)$ & $(31.14)$ & $(33.34)$ \\
\hline \multirow[t]{2}{*}{ Trade Defense Measures } & $-61.30^{* *}$ & $-61.30^{* * *}$ & $-53.57^{* * *}$ \\
\hline & $(25.24)$ & $(9.07)$ & $(9.89)$ \\
\hline \multirow[t]{2}{*}{ Tariff Measures } & $-57.56^{\star \star}$ & $-57.56^{* * *}$ & $-51.97^{* * *}$ \\
\hline & $(25.41)$ & $(10.42)$ & $(11.38)$ \\
\hline $\mathrm{N}$ & 3415.00 & 3415.00 & 3415.00 \\
\hline chi2 & 28.57 & 634.56 & 316.29 \\
\hline r2_overall & 0.08 & & \\
\hline r2_between & 0.68 & & \\
\hline r2_within & 0.07 & & \\
\hline
\end{tabular}

*** Significant at $1 \%$, or $\mathrm{P}<0.01$

** Significant at $5 \%$, or $\mathrm{P}<0.05$

${ }^{*}$ Significant at $10 \%$, or $\mathrm{P}<0.10$.

Numbers in parenthesis are standard errors.

Table 3: Estimations of import demand equations with specific trade measures and components of demand as explanatory variables.

in imports from Africa countries? This may have to do with the vertical specialization of global production network where the exports from African countries often end up being intermediate goods for the final goods often processed in OECD countries. The positive signs (not all significant) on direct consumption spending (i.e. household consumption), and government spending in a country also imply that exports of African countries in fact benefit from these non-investment spending.

These results are consistent with the expectation that higher spending in OECD countries would result in higher imports. But these demand components didn't have a strong impact on African exports as predicted by proponents of this line of argument. Given the weak significance of these spending components one could argue that in fact exports of African countries are immune from the sever shock of a global financial crisis to the extent that it is manifested in the demand decline. Freund alluded to this fact and stated that food and beverages were the least affected traded goods during the crisis years. Whether the same logic carriers on to the impact of trade measures, as Freund indicated, remained to be seen in the following results. The next results look into the impacts of aggregated (i.e., GTA color coded) trade measures on exports of African countries [3]. 
Citation: Lemi A (2016) Trade Measures of OECD Countries and the Decline in Exports of African Countries: Is Murky Protectionism Responsible? J Glob Econ 4: 171. doi:10.4172/2375-4389.1000171

Page 8 of 9

\begin{tabular}{|c|c|c|c|c|c|c|}
\hline & Standard & Standard & Heteroscedastic & Heteroscedastic & Standard & Heteroscedasti c \\
\hline & $\mathrm{b} / \mathrm{se}$ & $\mathrm{b} / \mathrm{se}$ & $\mathrm{b} / \mathrm{se}$ & $\mathrm{b} / \mathrm{se}$ & $\mathrm{b} / \mathrm{se}$ & $\mathrm{b} / \mathrm{se}$ \\
\hline \multirow[t]{2}{*}{ Household Consumption } & 4.13 & 4.13 & 4.13 & 4.13 & 2.54 & 2.54 \\
\hline & $(3.60)$ & $(3.60)$ & $(6.47)$ & $(6.47)$ & (3.07) & $(6.48)$ \\
\hline \multirow[t]{2}{*}{ Business Investment } & -1.42 & -1.42 & -1.42 & -1.42 & $-6.29^{* * *}$ & -6.29 \\
\hline & $(1.56)$ & $(1.56)$ & $(4.13)$ & $(4.13)$ & $(2.40)$ & $(4.13)$ \\
\hline \multirow[t]{2}{*}{ Government Spending } & 7.39 & 7.39 & 7.39 & 7.39 & $9.66^{*}$ & 9.66 \\
\hline & $(4.50)$ & $(4.50)$ & $(7.28)$ & $(7.28)$ & $(5.04)$ & $(7.47)$ \\
\hline \multirow[t]{2}{*}{ Exports } & $0.37^{\star \star *}$ & $0.37^{\star * *}$ & $0.37^{\star \star \star}$ & $0.37^{\star \star *}$ & $0.37^{* * *}$ & $0.37^{\star \star \star}$ \\
\hline & $(0.09)$ & $(0.09)$ & $(0.02)$ & $(0.02)$ & $(0.09)$ & $(0.02)$ \\
\hline \multirow[t]{2}{*}{ Common Language } & -6.69 & -6.69 & -6.69 & -6.69 & -5.44 & -5.44 \\
\hline & $(7.72)$ & $(7.72)$ & (8.08) & $(8.08)$ & $(7.36)$ & $(8.10)$ \\
\hline \multirow[t]{2}{*}{ Colonial Tie } & -15.43 & -15.43 & -15.43 & -15.43 & -15.67 & -15.67 \\
\hline & $(12.28)$ & $(12.28)$ & (9.91) & $(9.91)$ & $(12.49)$ & $(9.94)$ \\
\hline \multirow[t]{2}{*}{ Distance from Capital } & -0.00 & -0.00 & -0.00 & -0.00 & -0.00 & -0.00 \\
\hline & $(0.00)$ & $(0.00)$ & $(0.00)$ & $(0.00)$ & $(0.00)$ & $(0.00)$ \\
\hline \multirow[t]{2}{*}{ Amber Measures } & $49.40^{*}$ & $49.63^{*}$ & $49.40^{* \star *}$ & $49.63^{* * *}$ & & \\
\hline & $(27.44)$ & $(26.57)$ & $(10.32)$ & (9.35) & & \\
\hline \multirow[t]{2}{*}{ Restrictive Measures } & -0.23 & & -0.23 & & & \\
\hline & (3.28) & & $(5.57)$ & & & \\
\hline \multirow[t]{2}{*}{ Liberalizing Measures } & & 0.23 & & 0.23 & & \\
\hline & & $(3.28)$ & & $(5.57)$ & & \\
\hline \multirow[t]{2}{*}{ Export Subsidy } & & & & & $-26.71^{\star *}$ & -26.71 \\
\hline & & & & & $(11.13)$ & $(32.43)$ \\
\hline \multirow[t]{2}{*}{ Import Subsidy } & & & & & $-19.42^{*}$ & -19.42 \\
\hline & & & & & $(10.86)$ & $(20.55)$ \\
\hline \multirow[t]{2}{*}{ Quota } & & & & & $-21.17^{\star *}$ & -21.17 \\
\hline & & & & & $(10.10)$ & $(13.17)$ \\
\hline \multirow[t]{2}{*}{ Non-Tariff M } & & & & & -23.48 & -23.48 \\
\hline & & & & & $(17.46)$ & $(30.86)$ \\
\hline \multirow[t]{2}{*}{ Trade Defense Measures } & & & & & $-23.70^{* *}$ & $-23.70^{* * *}$ \\
\hline & & & & & (9.89) & $(6.40)$ \\
\hline \multirow[t]{2}{*}{ Tariff Measures } & & & & & $-20.41^{*}$ & $-20.41^{* *}$ \\
\hline & & & & & (11.11) & $(8.36)$ \\
\hline $\mathrm{N}$ & 3906.00 & 3906.0 & 3906.00 & 3906.00 & 3906.00 & 3906.00 \\
\hline chi2 & 70.96 & 70.96 & 324.99 & 324.99 & 74.56 & 309.48 \\
\hline r2_overall & 0.08 & 0.08 & & & 0.07 & \\
\hline r2_between & 0.13 & 0.13 & & & 0.14 & \\
\hline r2_within & 0.07 & 0.07 & & & 0.06 & \\
\hline
\end{tabular}

*** Significant at $1 \%$, or $\mathrm{P}<0.01$

** Significant at $5 \%$, or $\mathrm{P}<0.05$

*Significant at $10 \%$, or $\mathrm{P}<0.10$.

Numbers in parenthesis are standard errors.

Table 4: Estimations of import demand equations with trade measures and demand components as explanatory variables and accounting for commodity effects in addition to country effects.

The next results look into the impacts of aggregated (i.e. GTA color coded) trade measures on exports of African countries. Contrary to the GTA analysis of the measures, the results don't support the evaluation and hence the aggregation color codes that the GTA assigned to each trade measure (i.e., red, green and amber). It was expected that red and green trade measures would affect imports negatively and positively, respectively; whereas amber trade measures would not have any significant impact on trade flows. Contrary to this expectation, the results of the study indicate that only amber trade measures found to have positive and significant effects on imports of OECD countries from Africa. One could argue that this should not be taken as a GTA's evaluation error since this study is so focused only on African countries trade, which accounts for a smaller world trade share and only limited commodities. Second it may be the case that these trade measures (coded amber) exempt African countries' imports following the general preferential treatment of imports from Africa. Finally, a look back at the amber measures (Table 1 in appendix) reveals that in fact the amber measures almost entirely were implemented in 2009 and 2010 and the countries that implemented these amber measures were mostly the BRIC countries, which often give special focus/favor for countries in Africa.

Although the semi-aggregated trade measures result shows unexpected significant effects for amber trade measures, the results for the individual trade measures are mostly as expected. Most of the six trade measures selected by their coverage and importance for Africa (i.e. export subsidy, import subsidy, non-tariff measures, quota, tariffs, and trade defense measures) turn out to be statistically significant 
in negatively affecting OECD imports from Africa. Except export subsidies of OECD countries, all the other five trade measures had negative impacts on imports from Africa countries. This is expected except for the negative effect of import subsidy. One expects that import subsidies would promote more imports, not less. In further sensitivity analysis, this negative effect disappeared, which implies that the initial negative coefficient really had no economic significance than just statistical as seen from subsequent estimations.

Border measures were more important than behind-the-border measures as expected most of the crisis-era trade measures, which are theoretically trade limiting, are found to be the major impediments for flow of trade during the crisis years among OECD and African countries. Marginal effects analysis reveals that the effects of the trade measures on imports of OECD countries were in a factor of low 20s to middle 20 s when accounting for both country and commodity effects. In other words, imports of an OECD country which imposed one of these five trade measures declined by about $\$ 20$ million compared to an OECD country that didn't impose these trade measures. On the other hand, the impacts of demand components, especially government spending and exports, were only in a factor of between 0.37 to a little over 9 . That means, for instance, a one unit increase in exports of an OECD country resulted in only a less than one million (in fact $\$ 0.37$ million) increase in imports from African countries. The results of this study also shows that, unlike results from Henn and McDonald, which shows that behind-the-border measures (subsidies and bailouts) were more important than the border measures, in this study the border measures (tariffs, trade defense measures, quotas) turn out to be significant in the context of imports from Africa [11]. This doesn't mean that behindthe- border measures were not important for the case of imports from Africa; in fact export subsidies are one of the factors limiting imports although at a lesser degree than the above border measures. These results clearly demonstrate that trade measures, especially border measures, were harmful and had limited imports of OECD countries from Africa.

\section{Conclusions}

One of the results of this study highlights on the importance of murky protectionism (or creepy protectionism as some call it) in explaining the downturn of exports from African countries to their OECD partners. In fact, the results confirm that, unlike results from overall global trade flows, a fall in demand and its components are less important compared to the impact of trade measures in explaining the declines in exports of African countries. This result raises two issues, first that there is still wide open loopholes that even those OECD countries could use to damage global trade to such a global scale; second, these measures affect even those countries that are supposed to be protected under special privileges given their status in the world economic standing. As a result of these issues, Gregory et al. suggested that fixing these loopholes through tightened multilateral trade commitments by completing the Doha round negotiations might help to mitigate the root causes of these issues in the future [4]. As the successful conclusion of the Doha round is in doubt, frustrated by the multilateral level agreements, countries and regions are embarking on fast tracking regional trade agreements. Developing countries are the key players in this continue formation of regional trade blocs. The results of this study also provides some insight for countries creating pockets of regional trade blocs either with their neighboring countries and/or with their trading partners across oceans. In formulating rules of engagements for these regional blocs countries should specify rules for abnormal trade seasons to prevent countries from using downturns as pretext to impose protection tools not to further exacerbate and prolong impacts of economic crisis. To better understand the global nature of the contending explanations of the downturn in global trade, future studies should look into the importance of most of the alternative explanations (i.e. trade credits, demand and its components and trade measures, etc.), not just one at a time, to paint a clearer picture of the events right after the crisis and to rank the alternative explanations. Only then is it possible for multilateral organizations to close the loopholes often used by otherwise free market friendly countries.

\section{Acknowledgement}

I would like to thank participants of the Analysis of Contemporary Protectionism Conference organized by Global Trade Alert and African Center for Economic Transformation in Accra, Ghana for their comments and suggestions. I would also like to thank the Center for Economic Policy Research (CEPR) in UK for the financial support to undertake this study. All remaining errors are mine.

\section{References}

1. Behrens K, Gregory C, Giordano M (2010) Trade Crisis? What trade crisis? National Bank of Belgium.

2. Baldwin R, Evenett SJ (2009) Introduction and recommendations for the G20. Center for Economic Policy Research (CEPR) pp: 1-9.

3. Freund C (2009) The Trade Response to Global Downturns: Historical Evidence. Policy Research working paper. The World Bank.

4. Gregory R, Christian H, McDonald B, Mika S (2010) Trade and the Crisis Protect or Recover. Journal of International Commerce, Economics and Policy.

5. Erixon F, Sally R (2010) Trade, globalization and emerging protectionism since the crisis. European Centre for International Political Economy.

6. Bastos R, Pinodado J (2012) Trade credit during a financial crisis: A panel data analysis. Journal of Business Research 66: 614-620.

7. Anderson R, Tewolde T (2011) The Global Financial Crisis: Understanding the Global Trade Downturn and Recovery. The World Economy 34: 741-763.

8. Haddad M, Harrison A, Hausman C (2010) Decomposing the Great Trade Collapse: Products, Prices, and Quantities in the 2008-2009 Crisis. National Bureau of Economic Research.

9. Levchenko AA, Lewis LT, Tesar LL (2010) The Collapse of International Trade during the 2008-2009 Crisis: In Search of the Smoking Gun. National Bureau of Economic Research.

10. McKibbin WJ, Stoeckel A (2009) The Potential Impact of the Global Financia Crisis on World Trade. World Bank Policy Research.

11. Henn C, McDonald B (2011) Protectionist Responses to the Crisis: Damage Observed in Product-Level Trade. International Monetary Fund.

12. Mayer T, Zignago S (2011) Notes on CEPII's distances measures: The GeoDist database. CEPII Research and Expertise on World Economy. 